\title{
EFFICIENCY FINANCIAL RESOURCES IN VOCATIONAL EDUCATION
}

\author{
Nataliia KOVERNUK ${ }^{1}$ \\ Pereyaslav-Khmelnytskiy State Pedagogical University named after Grygiriy Skovoroda, Ukraine
}

\begin{abstract}
The purpose of writing is to research and analyze the effectiveness of financial resources in vocational education in Ukraine and develop practical recommendations for their improvement. To research and analyze the practices of formation and use of financial resources in vocational education. Research conducted by the methods of empirical knowledge, analysis, clustering, comparison, observation, synthesis, graphical analysis. The measures effective use of financial resources in vocational education in Ukraine. Methodology is actual work of scientists and researchers. Results are exploring of the practice of planning expenditures of state and local budgets for vocational education concluded that in planning expenditure dominates the normative method of budget planning. This discrepancy established approaches to the development of standards of employee's vocational institutions and expenditures of staff, on the one hand, and the required planning spending on vocational education. When planning educational grants for training labor to local budgets is determined by the amount of expenditures that are relevant to the intergovernmental transfers, which include, in particular, spending on vocational education. Although the legislation stipulates the independence of local budgets and calculation of expenditures that are relevant to the intergovernmental transfers should be done only to determine the amount of educational grants for training labor, in practice there is a significant limitation of the autonomy of local governments in the planning of local budgets. Thus, the deterioration of the efficiency of spending on vocational education due to increasing labor costs and labor charges. The reason for this was the dynamics as increased wages and a change in the number of employees engaged in technical and vocational education. Value. The analysis of public expenditure planning practices and local budgets for vocational education concluded that in planning expenditure dominates the normative method of budget planning. This discrepancy established approaches to the development of standards of employee's vocational institutions and expenditures of staff, on the one hand, and the required planning spending on vocational education. When planning educational grants for training labor to local budgets is determined by the amount of expenditures that are relevant to the intergovernmental transfers, which include, in particular, spending on vocational education. Although the legislation stipulates the independence of local budgets and calculation of expenditures that are relevant to the intergovernmental transfers should be done only to determine the amount of educational grants for training labor, in practice there is a significant restriction of local autonomy governments in local budget planning.
\end{abstract}

Key words: financial resources, the state budget, local budgets, expenditures on education, funding the educational sector, education.

JEL Classification: I22, 125, Z13

\section{Introduction}

Development of Vocational Education of Ukraine requires considerable upgrading to meet the needs of a modern economy, targeting this important sector to achieve European and world levels of educational standards, taking into account national circumstances, transformation of vocational education and training, as in almost all developed countries.

Problems of high labor updated dynamic changes in production technologies and sustainable demand for workers highly skilled, able to independently carry out complex work owning several related professions may be responsible for the results of their labor.

Requires qualitative changes in interaction of central and regional executive authorities and local governments, employers, customers training workers, is the social partners of vocational education institutions to enhance their economic stability, attract investment in their development, both motivating employers to create contemporary modern material-technical base of educational institutions, the selection of experienced

Corresponding author:

${ }^{1}$ Department of Finance, Monetary and Credit, Pereyaslav-Khmelnytskiy State Pedagogical University named after Grygiriy Skovoroda.

E-mail: kovernuk13@mail.ru 
engineering and teaching staff to train future workers' qualifications.

The society is growing concern that the quality of workers in a significant number of vocational schools do not meet the requirements of production, because the world is relevant profession skill generalists.

Incomprehensibility scientific forecasts of the labor market with current world trends becoming economy causes distortions in the formation of human resources, generates staffing crisis: lack of skilled workers and increased training in universities unclaimed experts.

Due to an underestimation of the human factor in the production and field services, the role of human capital in the establishment of a competitive economy, the importance of training, retraining and professional development of the production staff, their need for full development, lifelong learning reduces potential skilled workers compared with developed countries, there is a decline in the prestige of working professionals, lack of information about the demand for skilled workers.

Operation of the system of vocational education in Ukraine is complicated by the imperfect management, which does not use the possibilities of science. Content management activities are often based on inefficient forms, methods and means available to it a certain conservatism, professional unpreparedness of leaders at all levels to address strategic and tactical issues and development of education.

The determining factor in the success of modern vocational education is an effective system of funding. The modern practice of financial provision of vocational education inherent significant shortcomings that prevent full realization of the existing potential of social development. European integration of Ukraine creates new prerequisites for effective modernization of the system of financing vocational education. The real improvement financing vocational education, so that will increase cost-effectiveness and will improve the availability and quality of services is not possible without adequate scientific justification appropriate measures to optimize financial instruments

Spending considerable amounts of financial resources for vocational education driven by the desire to ensure social and individual benefits from such activities. Ultimately measure precisely meet the needs of the public determines the effectiveness of the use of funds, especially in vocational education. Evaluating the effectiveness is crucial for deciding on the appropriateness or unreasonableness of such expenditures. In the context of limited financial resources and unboundedness social needs, whenever necessary to isolate the costs that have a positive affect the country from those that do not generate the necessary benefits. In our opinion, the presence of a negative assessment regarding certain expenditures is primarily a causative factor for finding reserves in order to improve cost efficiency through active mechanism reform spending, adjusting their volume and structure, introduction of new approaches to the provision of public services and so on.

At present state Ukraine problem of low efficiency of expenditures refers to a number of problems that pose the greatest threat to social and economic development. In vocational education expenditure performance problems leading to the crisis in education, because lack of proper education of young people causes negative effects in future periods in life of man. Man, not having received the appropriate knowledge and proper training, acquire knowledge much more difficult in the future, and difficult adapting to a developed civil society. Because these people have no moral compass stable, easily manipulated by people and for a fee to involve illegal activities.

Under certain conditions, it even affects the security of the state and undermines the prospects of civilized development. Therefore, important to study the effectiveness of spending on vocational education, which will help to clarify the existing problems in this area and identify the reserves optimizing funding for vocational education.

\section{Systematic analysis of the quality of vocational education}

In vocational education expenditure performance problems leading to the crisis in education, because lack of proper education of young people causes negative effects in future periods in life of man. Man, not having received the appropriate knowledge and proper training, acquire knowledge much more difficult in the future, and difficult adapting to a developed civil society. Because these people have no moral compass stable, easily manipulated by people and for a fee to involve illegal activities. Under certain conditions, it even affects the security of the state and undermines the prospects of civilized development. Therefore, important to study the effectiveness of spending on vocational education, which will help to clarify the existing problems in this area and identify the reserves optimizing funding for vocational education.

Exploring issues of efficiency above all necessary to assess the value of the results to the committed expenditure. In the field of vocational education, concept results are quite voluminous and includes several elements - the number of customers of vocational education and ensuring its availability and quality of services providing vocational education. The number of young people who are studying in vocational schools and the level of coverage of vocational education determine the number of consumers of educational services.

Alongside 2010-2014. State budget expenditures per pupil VET steadily increased from 6.5 thousand. UAH. 
to 10.1 thousand. UAH. which was $55.4 \%$. It should be noted that the inflation rate for this period was $17.7 \%$.

Thus, the growth in spending per customer services far exceeded the rate of inflation in the country, indicating a decrease in efficiency spending on vocational education. It is worth noting that the increase in spending occurred largely at the expense of labor, as evidenced by the growth of their share in the structure of spending on vocational education. Thus, the deterioration of the efficiency of spending on vocational education due to increasing labor costs and labor charges. The reason for this was the dynamics as increased wages and the change in the number of workers employed in vocational education.

Conducting systematic analysis of the quality of vocational training in the context of funding requires a set of criteria that are used in the program-target method of budgeting. It should be noted that the analysis of any of the authorities with certain indicators inevitably faced with the problem of the adequacy of their choice.

The situation for the use of quality indicators of vocational education in the comprehensive analysis of the effectiveness of local budgets is complicated by the fact that in Ukraine at the local level are not usually used program-target method of budget planning and execution. In such circumstances, no approved quality criteria of vocational education, which indicate the effectiveness of expenditure. Therefore, the research funding of vocational education and its quality advisable to limit the most important quality criteria.

Experts in the field of vocational training substantiate the thesis that in the determination of functioning quality vocational education in the region should take into account three aspects - national, social and educational. In terms of quality of the national system of vocational education can determine the extent of compliance with the socio-economic conditions of society. In the social aspect of the quality system - a line of educational services available needs of the population, parents. The quality of education in the pedagogical aspect of compliance is measured by the content of vocational education to the current needs of the individual, the state and society based on variability, pedahohichky development-centered approach to education and training of young people training to working professionals. Thus, the effective quality of vocational education can be based on a subjective basis (results of the study thought their parents VET students and others.) In addition, objective basis (up licensing VET).

Given the lack of comprehensive studies of the quality of vocational education at the national level and the fact that Ukraine apply common approaches to planning and implementation of state and local budgets for vocational education, it is advisable to use the results of monitoring in a separate area to determine results of financing vocational education at the level of quality in the country. As the survey results as vocational education, its level is estimated to key stakeholders providing services of vocational education is quite high.

Fundamental importance for evaluating the effectiveness of state and local budgets have quality assessment services to their consumers. The results of a survey of parents, young people are enrolled in vocational schools generally correspond with the objective study of the quality of vocational education.

Create professional educational institutions of a new type of (multi-regional centers), the transfer of administrative and financial powers of the Ministry of Education at the regional level - these are the prospects for the evolution of the national system of vocational training.

The above position reflects, in particular, the new draft law "On Amendments to the Law of Ukraine" On vocational technical education ", which has filed for approval of the government.

So today, we have 1200 general vocational education. They were created in Soviet times and were "tied" to the industry. Many factories is not, at the same time started working successful new business. Therefore, you need a network of vocational training to match the needs of a modern economy.

The practice of regional centers of vocational education used in many EU countries, because they do not overcrowd the regional market experts of one profile and reduces the risk of unemployment. Also, increased flexibility regarding establishment of training according to the needs of the labor market and ensured availability of vocational education for citizens.

The bill, in addition to the regional centers of vocational training shall be determined following types of vocational schools, vocational college, vocational school and the center of training.

One of the advantages of decentralized implementation mechanisms should be multi-channel financing VET. The concept of reforming the system of national vocational education laid and an appropriate step - Amendments to Article 4 "Scope of application of the public-private partnership" Law of Ukraine "On public-private partnership» in terms of supplementing the list referred to in Article spheres - education.

In the education department acknowledged that today vocational training institutions are not separate issues in the disposal of material and financial resources. Then, of course, would be a logical output accounts special fund VET service of the State Treasury, as well as amendments to the Budget Code on the possibilities of directing funds from economic activities of educational facilities for the needs of "core" activities. VET clarify: we are not talking only about the repairs, modernization or purchase of agricultural machinery, fuel and lubricants, but the purchase of software, multimedia equipment, computerization of laboratories and offices and so on. 


\section{Scientific novelty of the results}

Scientific novelty of the results is to deepen theoretical positions essence funding allocations for vocational education and developing recommendations to improve the system of financing expenditure on vocational education. The most important results of the survey, describing its novelty is that for the first time theoretically singled components multifaceted services vocational education that show signs of public goods and private goods, as well as the content of positive externalities and the impact of services on the economy and justified on this basis, conceptual foundations focus on funding allocations for vocational education budgetary resources and money service users. Proved that optimal combination of these two sources of funding allocations for vocational education directly affects the quality of services vocational education and the needs of society and social justice in the country.

This made it possible to identify areas to improve the structure of sources of financing vocational education; improved set of measures to enhance the impact of financial instruments to stimulate providers of vocational training to more efficient implementation of the urgent tasks of the state, including increased financial autonomy of vocational schools, increasing the list of paid services, narrowing the terms of free provision of services student vocational schools, increasing the share of fathers compensation cost of food, predictions exemption from fees for services to socially vulnerable people, the right to dispose of their own income, a ban on receiving donations from parents and the transparency of financial resources. The approach, as opposed to the current, enables more comprehensively solve the problem of financial provision of vocational schools while excluding the negative impact on availability of vocational education and training with a positive impact on the economy; Scientific approaches to ensure the effective impact of financing costs of vocational education to achieve national economic development by implementing a set of measures that coordinate the formation of local spending on vocational education programs of socio-economic development of the region and identified the country's social policy priorities.

On this basis, the expediency of sharing these documents performance criteria, the harmonization of planning horizons, unification of responsible measures provided for synchronization and monitoring the use of funds for vocational education and the program of socio-economic development of the region; were further interpretation of the concept of "system of financing expenditure on vocational education" as a set of interrelated elements and intrinsic properties, which are in relationship to each other and which form a holistic education - providing financial resources, technical and vocational education in general, individual components of vocational education, enterprises, institutions and organizations and other economic entities that provide vocational education as well as programs and activities in the field of vocational education in order to achieve the planned economic results and / or social impact. Unlike existing treatments proposed definition of financing vocational education allows you to find all the components of this phenomenon; systematization forms of financing expenditure on vocational education to include program budgeting, which enables to optimize the use of limited budgetary resources to the highest priority programs and activities.

On this basis, reasonable application features Program Performance in funding allocations for vocational education, identified the potential benefits and possible risks. The recommendations for the introduction of program-targeted approach to spending on vocational education, implementation of which will contribute to the full implementation of the socioeconomic development; interpretation of the principles of financing costs in terms of singling out specific principles funding allocations for vocational education: completeness meet the needs of people who because of insufficient age alone cannot pay for and participate in the budget process; optimal combination of budgetary and non-budgetary sources of funding; Along with providing vocational education to meet the needs of related services; the need for compliance with national standards and meet the different needs of service users. The principles of funding allocations for vocational education enable to objectively determine priorities for improvement.

\section{Conclusions}

In summary, analyzing the deficiencies found funding of vocational education, manifested decrease in the number of vocational schools. This is due to the optimization of the network of educational institutions.

The analysis of the practice of planning expenditures of state and local budgets for vocational education concluded that in planning expenditure dominates the normative method of budget planning. This discrepancy established approaches to the development of standards of employee's vocational institutions and expenditures of staff, on the one hand, and the required planning spending on vocational education. When planning educational grants for training labor to local budgets is determined by the amount of expenditures that are relevant to the intergovernmental transfers, which include, in particular, spending on vocational education. Although the legislation stipulates the independence of local budgets and calculation of expenditures that are relevant to the intergovernmental transfers should be done only to determine the amount of educational grants for training labor, in practice there is a significant limitation of the autonomy of local governments in the 
planning of local budgets. Thus, the deterioration of the efficiency of spending on vocational education due to increasing labor costs and labor charges. The reason for this was the dynamics as increased wages and a change in the number of employees engaged in technical and vocational education.

\section{References}

The Budget code of Ukraine № 2456-VI of 12.02.2015. Retrieved from: http://zakon4.rada.gov.ua/laws/ show/2456-17/print 1393162468751735

Law of Ukraine "On public-private partnership". Retrieved from: http://zakon2.rada.gov.ua/laws/show/2404-17 Draft law of Ukraine "On professional education". Retrieved from: http://oblrada.cv.ua/downloads/ПО.pdf

Bogolib, T.M. (2006). Financial support for the development of higher education in the transformation period Kyiv: Education of Ukraine, p.324

Demyanyshyn, V. (2007). State funding and its features in modern conditions, World finance, № 2, p. 34-48.

Consumer price indices in 1993-2013. Retrieved from: http://www.ukrstat.gov.ua/

Levchuk, N. (2005). Inequality of access to education in Ukraine: social determinants and consequences. Demography and social economy, № 2, p. 148-158.

Polozenko, D. (2009). Problems of financing vocational education institutions in Ukraine. Finance of Ukraine Kyiv, №2, p. 22-31.

Sokolov, I. (2013). Programme-oriented budget management. Experience and prospects in Russia: monograph. Publishing home "Business" Ranhyhs, p. 246.

Chuchkova, G. (2004). Quality of education - the key problem of preservation and development of the region's education system. Quality preschool education: status, problems, prospects - Moscow, Publishing "GNOM \& D." p. 63-69.

George, S. (2008). In search of a compromise between state paternalism and financier, World Finance, № 4, p. 7-12.

\section{Наталья КОВЕРНИК}

\section{ОЦЕНКА ЭФФЕКТИВНОСТИ ИСПОЛЬЗОВАНИЯ ФИНАНСОВЫХ РЕСУРСОВ В УЧРЕЖДЕНИЯХ ПРОФЕССИОНАЛЬНО-ТЕХНИЧЕСКОГО ОБРАЗОВАНИЯ}

Аннотация. Целью работы является проведении исследований и анализа эффективности финансовых ресурсов в области профессионального образования в Украине и разработать практические рекомендации по их совершенствованию. Исследования, проведенные методами эмпирического познания, анализа, кластеризация, сравнение, наблюдение, синтез, графический анализ. Методикой является фактическая работа ученых и исследователей. Результатами статьи является исследование практики планирования расходов государственного и местных бюджетов для профессионально-технического образования пришли к выводу, что при планировании расходов преобладает нормативный метод планирования бюджета. Это несоответствие установленных подходов к разработке стандартов работников учреждений профессионального и расходов сотрудников, с одной стороны, и необходимые расходы на планирование в области профессионального образования. При планировании образовательных грантов для подготовки рабочей силы местным бюджетам определяется количеством затрат, которые имеют отношение к межбюджетным трансфертам, которые включают в себя, в частности, расходы на профессиональное образование. Хотя законодательство предусматривает независимость местных бюджетов и расчет расходов, которые имеют отношение к межбюджетным трансфертам, что должно быть сделано только для определения количества образовательных грантов для подготовки рабочей силы, на практике существует значительное ограничение автономии местных органов власти в планирование местных бюджетов. Таким образом, ухудшение эффективности расходов на профессиональное образование произошло в связи с увеличением расходов на оплату труда и расходы на работу. Причиной этого была динамика повышение заработной платы и изменение численности работников, занятых в области технического и профессионального образования. Значение. Актуальность темы исследования обусловлена поиском фактора успешности современного профессионально-технического образования, а именно эффективной системы ее финансирования. В современной практике финансового обеспечения профессиональнотехнического образования присущи значительные недостатки, препятствующие полноценной реализации имеющегося потенциала общественного развития. Европейская интеграция Украины создает новые действенные предпосылки модернизации системы финансирования профессиональнотехнического образования. Реальное совершенствование финансирования профессиональнотехнического образования, в результате чего произойдет повышение эффективности использования 
средств и улучшаться доступность и качество услуг, невозможно без должного научного обоснования соответствующих мероприятий по оптимизации финансового инструментария. На основе исследования предпочтений и ограничений различных форм финансирования профессионально-технического образования выяснено, наиболее оптимально соответствуют целям и задачам, предъявляемым, а также учитывают экономические условия. Доказано, что разнообразие различных форм финансирования создает предпосылки для развития системы профессионально-технического образования в соответствии с современными потребностями различных ее участников. Установлено, что наибольший положительный эффект можно получить в результате оптимального сочетания различных форм, способно наиболее полно обеспечить выполнение функций профессионально-технического образования. 